\title{
Editorial: Main results from Engine Combustion Network - France project: characterization of new experimental facilities and study of Diesel evaporation and combustion processes using advanced optical diagnostics
}

\section{Éditorial: principaux résultats du projet Engine Combustion Network - France : caractérisation de nouveaux dispositifs expérimentaux et études des processus d'évaporation et de combustion de type Diesel à partir de diagnostics optiques avancés}

\author{
Christine Rousselle ${ }^{1, *}$ and Gilles Bruneaux ${ }^{2}$ \\ ${ }^{1}$ Université d'Orléans, 8 rue Léonard de Vinci, 45072 Orléans Cédex, France \\ ${ }^{2}$ IFP Energies nouvelles, 1 et 4 avenue de Bois Préau, 92852 Rueil-Malmaison Cedex, France
}

Received: 28 September 2020 / Accepted: 7 October 2020

\section{Full abstract}

Reducing the consumption of hydrocarbon fuels within the transportation sector remains one of the most important challenges to reduce greenhouse gas emissions. Even if the development of electric vehicles is regarded as one of the preferred routes in coming years, most of the future projections agree that hybrid powertrains will continue to have a large market share in the next decades as underlined recently by Reitz et al. [1]. Therefore, improvements in internal combustion engine efficiency are essential, in addition to the fact that internal combustion engine remains an effective and low risk technology pathway for energy transition.

The performance of combustion engines has significantly improved in terms of thermal efficiency, thus contributing to significantly reduced levels of $\mathrm{CO}_{2}$ and exhaust gas emissions as the result of advanced research and development for combustion systems. Engine CFD codes can be very powerful tools to support advanced combustion system development if the numerical simulations can predict with sufficient accuracy the complex physical processes occurring. However, the models used in present CFD codes still have shortcomings, ultimately meaning that engine combustion designs and fuel efficiency gains still have the potential for optimization. For this reason, an

\footnotetext{
* Corresponding author: christine.rousselle@univ-orleans.fr
}

important ongoing contribution of engine research aims at gaining a more precise understanding of the physical phenomena occurring in combustion chambers, such as cavitating high pressure internal injector nozzle flows, primary and secondary atomization of very dense sprays, multicomponent fuel evaporation, turbulent mixing, complex chemistry ignition, heterogeneous combustion structure, highly sooting flames... By characterizing such phenomena requires the development and application of advanced optical diagnostic techniques, capable of performing in-situ measurements of physical parameters during the injection and combustion events. Such experimental data is required to support the development of more predictive models for engine CFD.

To tackle this challenge a group of international laboratories, the ECN (Engine Combustion Network: http:/ www.sandia.gov/ecn/), initiated in 2008 a collaborative and voluntary research effort to develop an international database aimed at providing the necessary information for detailed CFD model validation and to coordinate experimental and modelling activities around this database. Since its inception, this collaboration has experienced strong growth, as underlined in Picket et al. [2]. The latter underlines the growing interest of the engine combustion community, explained by the scientific relevance of the research (relying on international collaboration to address the scientific challenges facing the community), as well as the international visibility as a result of participation in the network. 
The collaborative project "ECN France", funded by the French National Research Agency (ANR-14-CE22-0015708 01), was carried out in this context from 2014 to 2019. It brought together four French research laboratories that have gained expertise in the development and application of advanced optical diagnostics for engine combustion research. Its objective was to promote the active participation of the French engine combustion community within the ECN, and to develop innovative diagnostics for Diesel injection and combustion. The research performed was based on the ECN spray A condition, representative of harsh pressure and temperature conditions, as defined by ECN (in particular injection of $n$-dodecane fuel at $363 \mathrm{~K}$ into gas at $900 \mathrm{~K}$ and $22.8 \mathrm{~kg} / \mathrm{m}^{3}$ ).

This special issue presents results from this collaborative project with five new papers [3-7] covering all aspects of the work performed, from standardization issues to advanced optical diagnostic developments.

Experience from previous ECN research has taught us that repeating similar experiments in different facilities (i.e. standardization) is both extremely challenging and essential, since it is the prerequisite to enable the construction of a coherent cooperative database, and it tends to reveal hidden biases and uncertainties due to the measurement techniques or the set-up itself. As an example, the first two ECN workshops in 2011 and 2012 were mainly dedicated to these standardization issues, and more recent workshops continue to address it.

The first two papers [3, 4] fall within this context to present how the experimental conditions achieved in two new French facilities, both based on measurements performed within a Rapid Compression Machine, can reach the standards proposed by ECN. The accuracies of initial conditions themselves are presented in Ben Houidi et al. [3] and a focus on data obtained for spray and combustion developments is addressed in Hespel et al. [4]. All data are compared to the IFPEN database, which was already shared within the ECN, and obtained in a precombustion chamber. It is interesting to note that this is the first time that configurations other than constant volume or constant flow cells are used to produce spray A ECN data, bringing complementary information to the ECN state of the art.

The three other papers are dedicated to the results obtained to provide new insights on the physical processes occurring during the atomization of the dense liquid spray [5], the combustion process [6] and soot formation [7] by implementing advanced measurement techniques.

Kanjanasakul et al. [5] evaluate the possibility to use rainbow refractometry laser diagnostic to study fuel droplets in high-pressure conditions representative of trans-critical conditions, such that it can exist in Diesel operating conditions. New methodology for processing the rainbow signals has generated a positive return on the simultaneous measurement of the ethane vapor concentration around the droplets as well as the temperature and size of liquid droplets. All these parameters will be then useful to improve the knowledge on evaporation processes when liquid fuel is injected in trans-critical conditions.
Strozzi et al. [6] used simultaneous high-speed $\mathrm{OH}^{*}$ chemiluminescence and two-pulse $355 \mathrm{~nm}$ planar laser induced fluorescence to provide unique data on the time evolution and the repeatability (and stochasticity) of the early stages of both cool flame and hot ignition phenomena. These new time-resolved data provide further insights into the dynamics of the spray A ignition and bring some elements on the underlying mechanisms to help the validation and improvement of numerical models devoted to diesel spray ignition.

In Patel et al. [7] conducted unique experiments in order to study the effect of the presence of $\mathrm{CO}_{2}$ and $\mathrm{H}_{2} \mathrm{O}$ in ambient gases on soot formation thanks to the flexibility of the experimental set-up in adjusting the initial composition of ambient gases. It was pointed out that both reduce soot mass fraction but with more $\mathrm{H}_{2} \mathrm{O}$ impact. It is also found that $\mathrm{CO}_{2} / \mathrm{H}_{2} \mathrm{O}$ mixture compositions representative of ECN preburn conditions significantly reduce on soot formation, pointing out that this effect should be taken in account when using ECN data to validate soot models.

\section{References}

1 Reitz R.D., Ogawa H., Payri R., Fansler T., Kokjohn S., Moriyoshi Y., Agarwal A.K., Arcoumanis D., Assanis D., Bae C., Boulouchos K. (2020) The future of the internal combustion engine, Int. J. Eng. Res. 21, 1, 3-10. https://doi.org/ 10.1177/1468087419877990.

2 Pickett L., Bruneaux G., Payri R. (2020) Engine combustion network special issue, Int. J. Eng. Res. 21, 1, 11-14. https://doi.org/10.1177/1468087419882247.

3 Ben Houidi M., Hespel C., Bardi M., Nilaphai O., Malbec L.M., Sotton J., Bellenoue M., Strozzi C., Ajrouche H., Foucher F., Moreau B., Rousselle C., Bruneaux G. (2020) Characterization of the ECN spray A in different facilities. Part 1: boundary conditions characterization, Oil Gas Sci. Technol. - Rev. IFP Energies nouvelles 75, 35. https://doi.org/10.2516/ogst/ 2020023.

4 Hespel C., Ben Houidi M., Ajrouche H., Foucher F., Haidous Y., Moreau B., Nilaphai O., Rousselle C., Bellenoue M., Claverie A., Sotton J., Strozzi C., Bardi M., Bruneaux G., Malbec L.M. (2020) Characterization of the ECN spray A in different facilities. Part 2: spray vaporization and combustion, Oil Gas Sci. Technol. - Rev. IFP Energies nouvelles 75, 78. https:// doi. org/10.2516/ogst/2020070.

5 Kanjanasakul C., Grisch F., Saengkaew S., Gréhan G. (2020) Optical characterization of ethane droplets in the vicinity of critical pressure, Oil Gas Sci. Technol. - Rev. IFP Energies nouvelles 75, 59. https://doi.org/10.2516/ogst/2020039.

6 Strozzi C., Ben Houidi M., Sotton J., Bellenoue M. (2020) Analysis of ECN spray A ignition in a rapid compression machine using simultaneous $\mathrm{OH}^{*}$ chemiluminescence and formaldehyde PLIF, Oil Gas Sci. Technol. - Rev. IFP Energies nouvelles 75, 38. https://doi.org/10.2516/ogst/2020036.

7 Patel C., Hespel C., Nguyen T.L., Foucher F., Mounaïm-Rousselle C. (2020) Effect of exhaust gas recirculation composition on soot in ECN spray A conditions, Oil Gas Sci. Technol. - Rev. IFP Energies nouvelles 75, 34. https://doi.org/10.2516/ogst/2020028. 